\title{
PETROLOGY AND URANIUM POTENTIALITY OF ABU-RUSHEID SUBSURFACE GNEISSES, SOUTHEASTERN DESERT, EGYPT.
}

EL-MEZAYEN ${ }^{-1}$, A. M, FALHAM M. ORABY ${ }^{2}$, ABU ZEID ${ }^{2}$, E.K, MAHMOUD ${ }^{2}$, M. A. M. AND SHALAN ${ }^{2}$, A. S.

${ }^{1}$ Faculty of science, El-Azhar University, Nasr city, Cairo, Egypt.

${ }^{2}$ Nuclear Materials Authority, Cairo, Egypt, B.O. Box: 530 El-Maadi.

\section{ABSTRACT}

The subsurface gneisses of Abu Rusheid area have been studied perfectly through two pre-pilot drillholes BH1\&BH2 with depths of 70, 54m respectively comprising the geologic, petrographical and mineralogical studies applied to the picked core samples to throw light on their U-potentiality.

Lithologically, the core samples of BH1 are mainly (from top to bottom): quartz-hornblende schist, serpentinite, whitish gray granoblastic gneiss alternating with pinkish gray porphyroblastic gneiss with sharp contacts. While, the core samples of the BH2 are mainly (from top to bottom) whitish gray granoblastic gneiss, pink granoblastic gneiss, quartz-feldspar-biotite schist, quartz-hornblende-biotite schist, mica schist, talc carbonate, gray granoblastic gneiss with migmatite zone and finally whitish gray granoblastic gneiss.

Petrographic investigation revealed that, the pinkish dark-gray porphyroblastic gneiss of BH1 and pinkish granoblastic gneiss of BH2 are petrographically identical to granodioritic rocks (clearly granitoid composition, lake of pebbles and pelitic minerals such as cordierite and kyanite) alternated with whitish gray granoblastic gneiss of sedimentary origin (presence of the fragments and pelitic metasomatic minerals; cordierite, kyanite, garnet and anthophyllite). The metamorphic sequence most likely represents a sequence of pelites and psammites, intruded by megacrystic granitoid injections from external sources below, then metamorphosed to an amphibolite-granulite facies assemblage. These results are important for understanding the tectonometamorphic evolution of the Abu-Rusheid area and add to the previous information about Hafafit metamorphic core complexes in the Eastern Desert, their mode of formation and formation of the present modeling are critical to future modeling of the overall tectonic evolution of the Arabian-Nubian Shield.

Mineralogical study indicated that, thorite and uranothorite are the most predominant radioactive minerals in the studied boreholes in addition to the uranophane that recorded in the zone between 23-24m in BH1. Other radioelements-bearing minerals were recorded such as columbite, pyrochlore, betafite, samarskite, fergusonite and zircon associating rare metals (bismuth and molybdenite) and base metals (pyrite, sphalerite and iron oxides).

Keywords; pre-pilot drillholes. Granoblastic gneiss. Cordierite. Uranium. Abu Rushied. Egypt.

\section{INTRODUCTION}

The Egyptian Eastern Desert, Sudan, western Saudi Arabia, Ethiopia, Eritrea, Jordan and Yemen belong to the so-called Arabian Nubian Shield (Fig. 1), which is characterized by four main rock sequences: (i) an island arc assemblage; (ii) an ophiolite assemblage; (iii) a gneiss assemblage that comprises the core complexes; and (iv) granitoid intrusions (Abdel Naby et al., 2000; Abd El-Naby and Frisch, 2002). The core complexes and the major tectonic trend on both sides of the Red Sea strike northwest- southeast (Fig.1) and are related to a crustal-scale sinistral shear zone called the Najd Fault System (Stern, 1985).

Sikait-Nugrus-Abu Rushied areas at South Eastern Desert (SED) are representing the southeastern sector of the Hafafit metamorphic complex. It occupies high-grade infrastructural rock assemblages, which are represented by meta- morphic volcano-sedimentary series, quartzofeldspathic gneisses of tonalite and granitic composition, and amphibolites (Fig. 2). They are over thrusted, via the Nugrus thrust zone by an obducted ophiolitic mélange. This mélange represents the supra-structural assemblage and consists of large nappes obducted over the infrastructure (Kroner et al., 1987).

The exploration efforts, carried out by the Nuclear Materials Authority of Egypt (NMA) at Abu Rusheid area, led to the discovery of the uranium mineralization at some shear zones occur within mineralized gneissic rocks and at the thrust plane between ophiolite mélange and these rocks. To explore the uranium mineralization and associated economic minerals at deeper levels and also to obtain more geological data of Abu Rusheid area, a drilling program was carried out by Diamond core drilling. 
El-Mezayen, et al.,

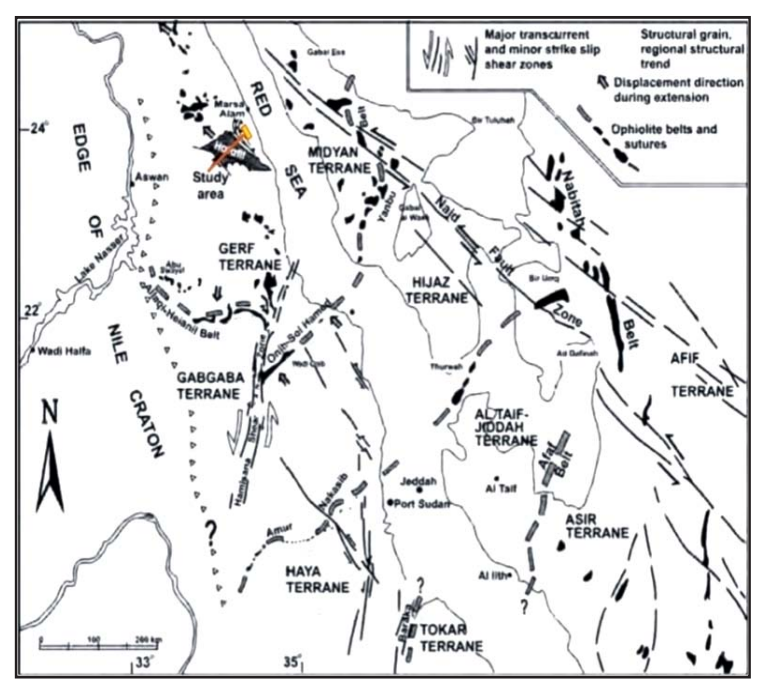

Fig. (1). Schematic tectonic map of the Arabian

Nubian Shield showing ophiolite belts, major structures and lineaments (Kröner et al., 1992). $\nabla$ ( Study area).

This study is concerned with the subsurface geology, petrology and mineralogy of the core samples recovered from two pre-pilot drillholes $\mathrm{BH} 1 \& \mathrm{BH} 2$ with depths of 70, $54 \mathrm{~m}$ respectively, as well as modified the geotectonic evolution modeling for the Migif-Hafafit, Nugrus, Abu Rusheid and Ghadir areas.

\section{GEOLOGIC SETTING}

\section{A) Surface Geology}

$\mathrm{Abu}$ Rusheid area is located at the Southern part of the Eastern Desert of Egypt, about 45 $\mathrm{km}$ to the Southwest of Marsa Alam city (Fig. 2a). It occupies approximately $73.5 \mathrm{~km}^{2}$. It is bounded by Latitudes $24^{\circ} 36 \varnothing 43^{\prime \prime}$ and $24^{\circ} 38 \phi$ $26^{\prime \prime} \mathrm{N}$ and Longitudes $34^{\circ} 46 \varnothing 00^{\prime \prime}$ and $34^{\circ} 46 \varnothing$ 35 " E. Abu Rusheid-Sikait area is bordering to the major shear zone known as the Nugrus thrust fault (Greiling et al., 1988) or the Nugrus strikeslip fault (Fritz et al., 1996) and/or Sha'it-Nugrus shear zone (Fowler and Osman, 2009). Abu Rusheid-Sikait granitic pluton elongated in NWSE (12 km in long) and thinning in NE-SW (3 $\mathrm{km}$ in width), (Fig. 2b). Abu Rusheid area is located between a major thrust to the NE and a minor one to the SW. Semi-detailed geologic map of Abu Rusheid cataclastics and surrounding rocks was prepared out based on field relations and structural observation (Fig. 2c). The main rock units encountered in this area are grouped as follows; - (a) Gneissic rocks (b), Opiolitic mé- lange, (c) granitic rocks, (d) post-granitic dykes and veins. The gneissic rocks occur in the field down thrusted the ophiolitic mélange and foliated in ENE-WSW direction. The lithologic contacts with ophiolitic melange, where exposed, are tectonized and well defined. These rocks occupy the core of the granitic pluton and cross cut by three shear zones; the first two zones extend NNW-SSE, while the third extends ENE-WSW. The study area $\left(1.0 \mathrm{~km}^{2}\right)$ is characterized by low to moderate topography and highly tectonized rocks. Gneissic rocks are characterized by containing mineralization as uranium and associated minerals. The ophiolitic mélange, consisting of ultramafic rocks and layered metagabbros set in metasedimentary matrix. The latest Pan-African activity in the mapped area is represented by a suite of leucogranites, pink granites and postgranitic dykes, veins and pegmatitic body. The younger granites are locally developed along thrust faults and containing numerous enclaves from older rocks particularly mica schist. Several masses of these granites are found in Wadi Nugrus-Abu Rusheid. The granitic rocks occupy the major part of the mapped area and represented from the NW direction by porphyritic biotite granites followed by deformed biotite granites and two mica granites, whereas the muscovite granites occupy the SE part of the pluton (Ibrahim et al., 2004).

\section{B) Sub-surface geology of Abu Rusheid gneissic rocks}

According to the discovery of some surfacial uranium mineralization at the studied area (Ibrahim et al., 2002 and 2004), and depending on ground geophysical surveys which were conducted to explore the mineralized zones at depth and detailed surface geology, diamond core drilling project are carried out to complete the information about the uranium mineralization at $\mathrm{Abu}$ Rushied area. It was suggested by NMA to obtain more geological and mineralogical data of subsurface anomalies, by the studying the core samples from two pre-pilot drillholes (Fig. 3). The two pre-pilot drillholes will be discussed in the following paragraphs.

\section{Borehole (1) (BH1)}

This borehole is vertical $\left(90^{\circ}\right)$; it had been drilled to about $70 \mathrm{~m}$ depth from the topographic 


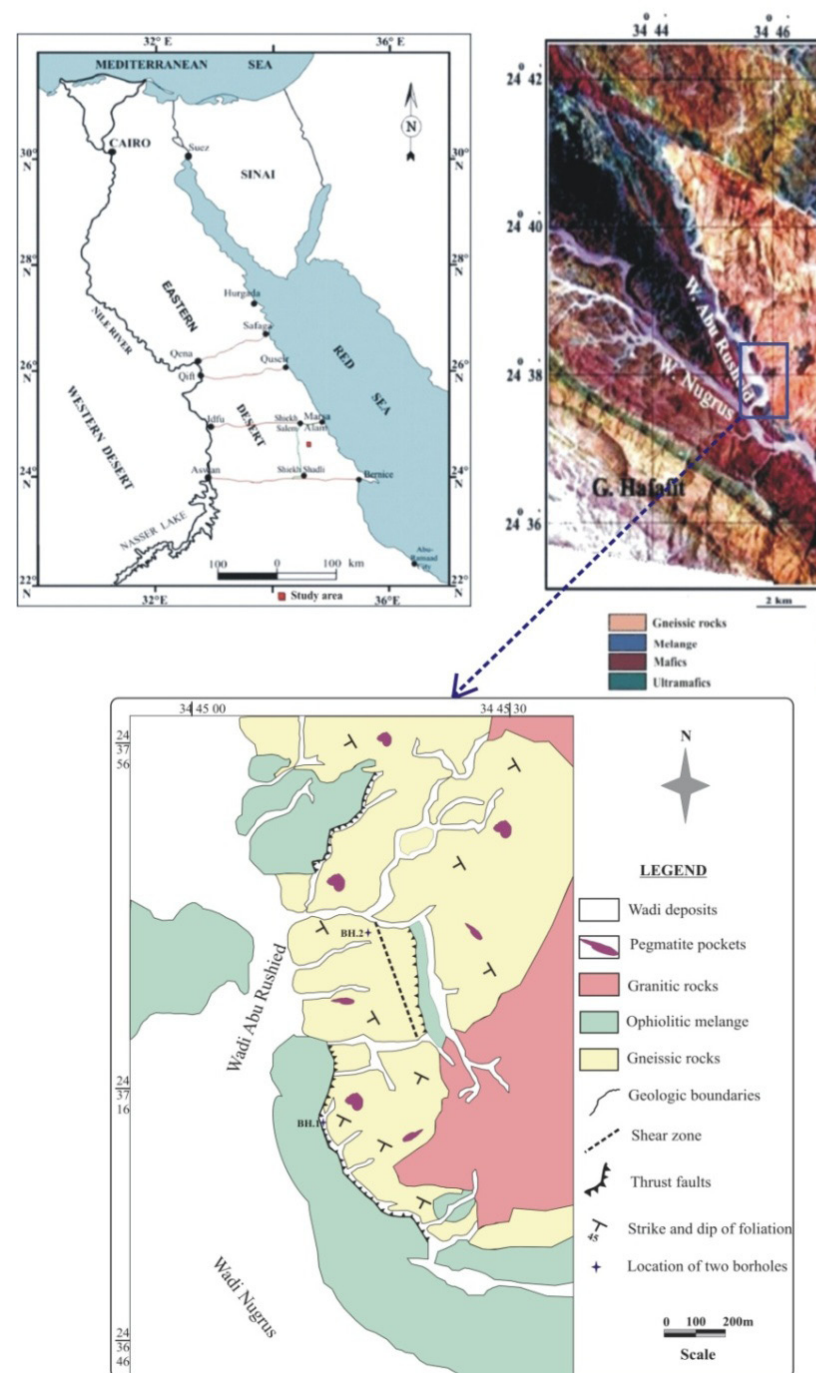

level. The main target for that borehole is to intersect the contact between the studied gneiss and the ophiolite as well as to characterize the behavior and distribution of uranium mineralization and associating economic minerals at deeper levels, (Fig. 3).

The lithostrtigraphic sequence is constructed for the studied borehole based on the morphological features and petrographical examination, (Fig. 4). It is clear that the subsurface units are lithologically represented mainly (from top to bottom) by quartz-hornblende schist $(13 \%$ of this borehole), serpentinite, (less than 1\%) whitish gray granoblastic gneiss $(70 \%$ to $75 \%)$ alternating with pinkish gray porphyroblastic gneiss $(20 \%$ to $27 \%)$ with sharp contacts.

The studied core samples of quartz-hornblende schist are blackish gray color, fine- to medium-grained, composed mainly of quartz and hornblende with schistose structure $(12 \mathrm{~m}$

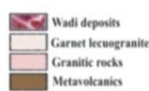

Fig. 2: a- Location map of the study area. b- Landsat image of the study area. c- Geologic map of the study area showing location of the studied boreholes, South Eastern Desert, Egypt, modified after Ibrahim et. al., 2004.

thickness). It is underlained by thin layer ( $1 \mathrm{~m}$ thickness) of serpentinite characterized by reddish to yellowish white colors and medium grain size, (Fig. 5a).

Gneissic rocks of this borehole occupy a very thick zone (about $57 \mathrm{~m}$ ) composed of alternating layers of whitish gray granoblastic gneiss and pinkish gray porphyroblastic gneiss. The contact of the gneissic rocks with the serpentinite rocks is marked by pale green gneissic layer characterized by presence of greenish quartz that belongs to granulite metamorphic facies (Hyndman., 1985), (Fig. 5b).

The whitish gray granoblastic gneiss are characterized by regular grain size showing a moderate to well-developed millimeter-spaced gneissic banding and contain pinkish fragments of another rock type, (Fig. 5c). They are composed mainly of quartz, plagioclase, rare k-feldspar, biotite and muscovite. Sulphides are en-

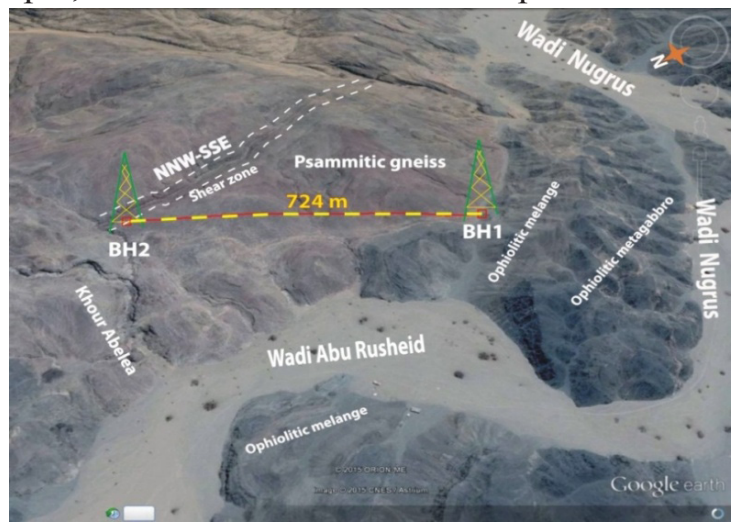

Fig. 3: Landsat image showing the location of the two boreholes, Abu Rusheid, SED, Egypt. 


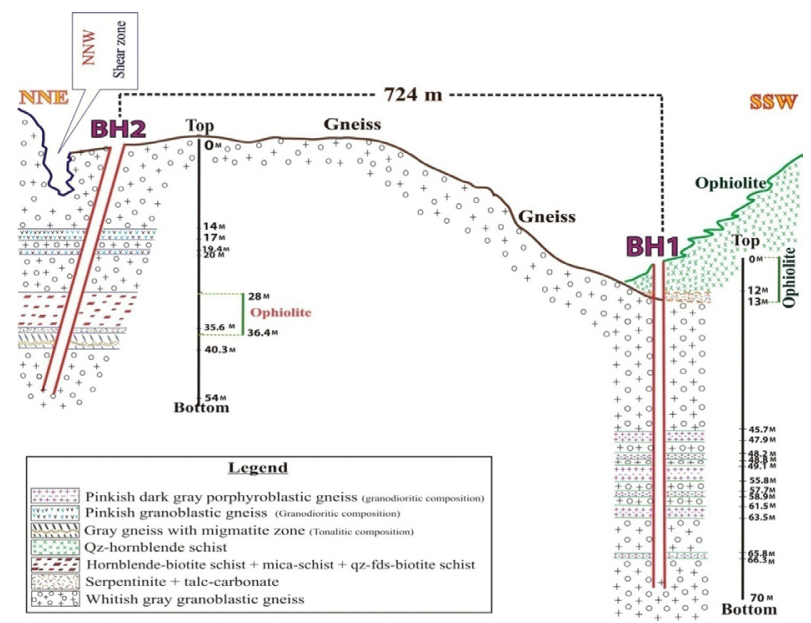

Fig.4: Schematic cross section showing the subsurface geology of the two boreholes. countered as dissimenations in the host gneisses or deposited along the fracture planes (Fig. 5d).

The pinkish gray porphyroblastic gneiss is medium to coarse-grained characterized by variability in grain size and whitish dark gray to pinkish dark gray colors. They are composed mainly of quartz, plagioclase, k-feldspar and biotite and show well-developed porphyroblastic texture, (Fig. 5e). They are also moderately foliated; the foliation is defined by flattened biotiterich streaks and indistinct, elongated lithosomes of quartz and feldspar and invaded by numerous thin pegmatite veinlets. There is a clear sharp contact between porphyroblastic gneiss and granoblastic gneiss, (Fig. 5f).
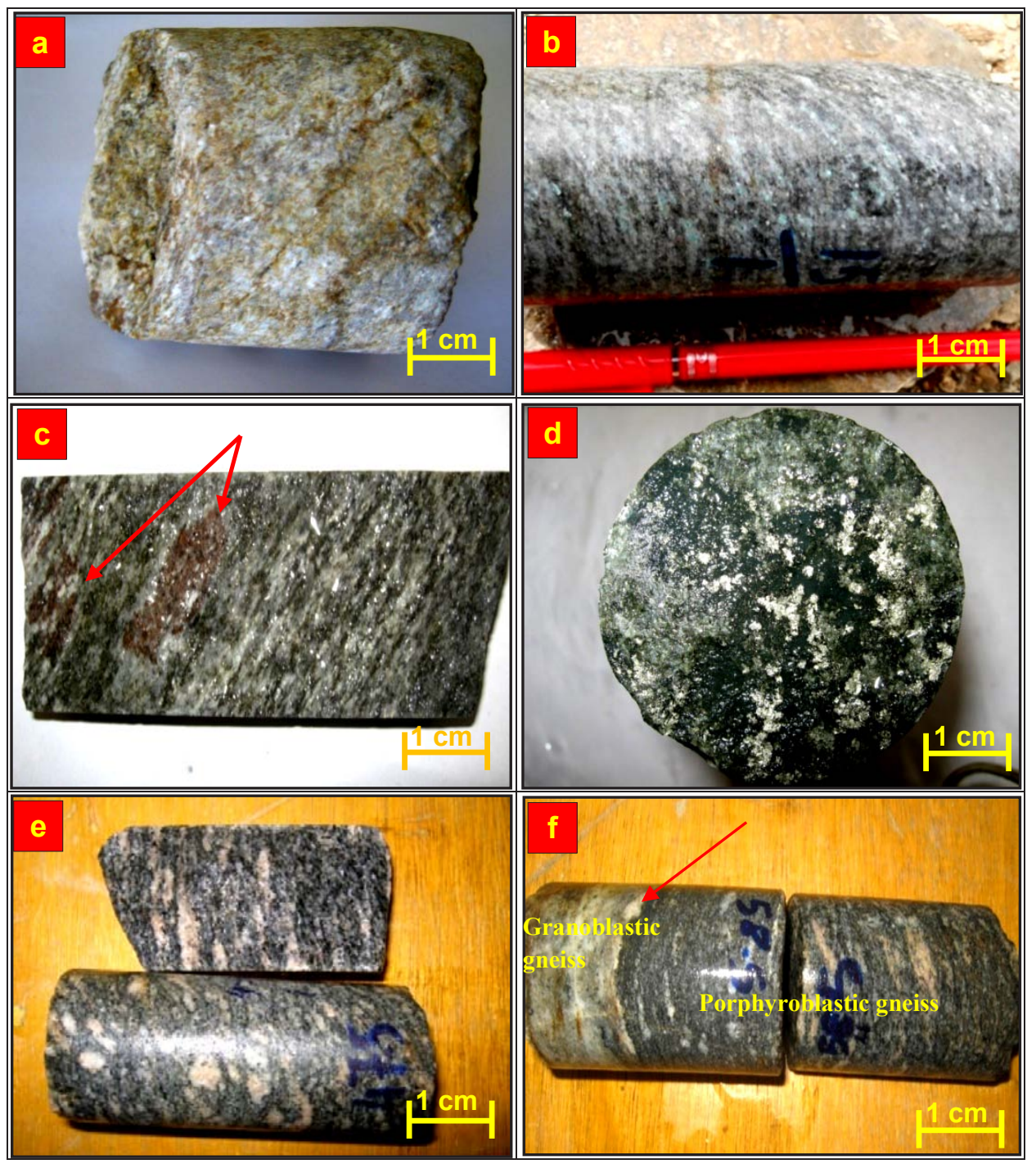

Fig. 5: Photographs of core samples, Abu Rusheid borehole No. 1 showing:- a- Serpentinite core sample. b- Greenish gray granoblastic gneiss. c- Well-developed millimeter-spaced gneissic banding and contain pinkish fragments of another rock type. d- Sulphides along the fracture plane. e- Porphyroblastic texture in porphyroblastic gneiss. f- Sharp contact between porphyroblastic gneiss and granoblastic gneiss. 


\section{Borehole (2) (BH2)}

Bore hole 2 (BH2) was drilled to about $54 \mathrm{~m}$ depth from the topographic level with inclined dip $76^{\circ}$ towards the east direction. The main target for this borehole is to intersect the NNW shear zone at depth as well as to study the distribution of uranium mineralization and important economic minerals at deeper levels using diamond core drilling, (see fig. 3). The picked samples were studied and categorized in lithostratigraphic sequence, (Fig. 4). Samples of the studied borehole are mainly comprised of (from top to bottom): whitish gray granoblastic gneiss, pink granoblastic gneiss, quartz-feldsparbiotite schist, quartz-hornblende-biotite schist, mica schist, talc carbonate (mélange rocks), gray granoblastic gneiss with migmatite zone and finally whitish gray granoblastic gneiss.

The whitish gray granoblastic gneisses are the major category representing about $65 \%$ to $70 \%$ of the two boreholes. It represents the uppermost layer (14.4m thickness) and lowermost layer $(14 \mathrm{~m})$ of the succession and also appears in the middle of the column occupying the depth from $16 \mathrm{~m}$ to $28 \mathrm{~m}$ interrupted by thin layer of pinkish granoblastic gneiss $(0.4 \mathrm{~m})$, (Fig. 4$)$. The first four meters are characterized by presence of iron staining and cubic voids refilled by secondary materials where desulphitization of pyrite crystals occurs, (Fig. 6a). This zone is subjected to shearing and fracturing which show obvious signs of brecciation along the fractures, (Fig. $6 b)$.

Pinkish granoblastic gneiss is present as two bands sandwiched by the whitish gray granoblastic gneiss; the first is estimated as $3.6 \mathrm{~m}$ thickness and the second as $0.5 \mathrm{~m}$ thickness, (see fig. 4c). Pinkish granoblastic gneiss has granitic composition but with metamorphic fabrics. The contact between the pinkish granoblastic gneiss and whitish gray granoblastic gneiss is marked by sharp contact, (Fig. 6c). Some samples exhibit porphyroblastic texture, where the proper granite are being retained and present as granitic fragments wrapped by sheath of foliated minerals, (Fig. 6d).

Schistose rocks represent the metasedimentary matrix of another ophiolitic mélange at borehole (2). They could be categorized according to their composition into quartz-feldspar-biotite schist, hornblende-biotite schist and mica schist. They directly underlay the whitish gray granoblastic gneiss occupying the zone from $28 \mathrm{~m}$ to $36.4 \mathrm{~m}$. They are hard and compacted rocks characterized by schistose structure and black color with variable degrees. The mica schist is overlained by thin layer of talc-carbonates as metamorphosed ultramafite thrusting over the previous succession, (Fig. 6e).

Finally the gray granoblastic gneiss with migmatized zone directly underlies the schistose unit marked by sharp contact. It is characterized by gray to black color, medium- to coarse-grained $(2-5 \mathrm{~mm})$ and composed mainly of quartz, plagioclase and biotite as essential minerals. The migmatized zone occurs within this band at the contact with the whitish gray granoblastic gneiss. Some core samples exhibit signs of migmatization manifested by presence of segregations of light

leucosomes with variable thicknesses parallel to the host rock foliation, giving them welldeveloped stromatic structures, (Fig. 6f).

\section{Petrography of boreholes}

The microscopic study handles the gneissic rocks in the boreholes only where the gneisses are the major category representing about $70 \%$ of the two boreholes and considered as the most important units from the mineralized point of view.

\section{A) Gneissic rocks of borehole (1) (BH1)}

Megascopically, the gneissic rocks are massive, medium to coarse grained with whitish gray color. Gneissose texture is defined by a dimensional preferred orientation of biotite flakes within predominantly quartz and feldspars.

Whitish gray granoblasticgneiss is considered as psammitic gneiss, composed mainly of quartz, plagioclase, potash feldspar, in addition to less amount of biotite and muscovite. It ranges in composition from quartz-plagioclase, (13m-3.2m zone), bioite-muscovite-cordieritegarnet-quartz-feldspars, $(13.2 \mathrm{~m}-37.5 \mathrm{~m}$ zone $)$ to bioite-cordierite-anthophyllite-quartz-feldspars, $(37.5 \mathrm{~m}-45.7 \mathrm{~m}$ zone).Textures are medium- to coarse-grained, gneissic to blastomylonitic. 

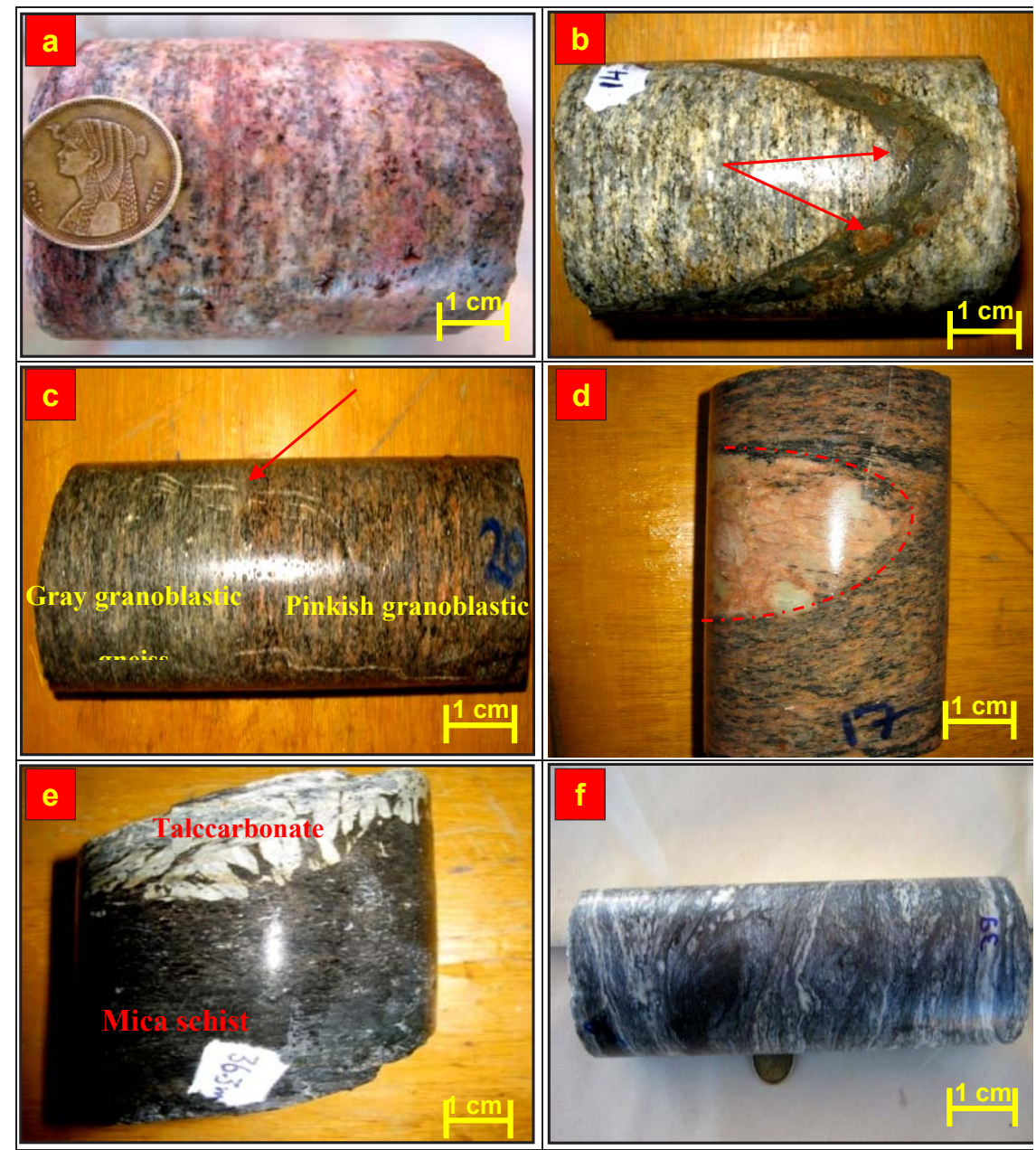

Fig. 6: Photographs of core samples, Abu Rusheid borehole No. 1 showing: - a- Iron oxides refilled the vugs of the dissolved pyrite cubes. b- Brecciation along the fractures. c- Sharp contact between pinkish granoblastic gneiss and whitish gray granoblastic gneiss. d- Pegmatitic pocket as original geological feature of the primary granitoid. e- Talc-carbonate overlies directly mica shist. f- Stromatic layering in migmatitic gray granoblastic gneiss.

Quartz is the most dominant mineral; it occurs in three forms reflecting three stages with variable degrees of dynamic metamorphism. The first gentle stage is characterized by rounded to subrounded crystals with sutured or corroded boundaries preserving their wavy extinction, (Fig.7a). The second moderate stage comprises the flattened or lenticular crystals forming fuzzy texture and characterized by undulose extinction, (Fig.7b). The final intensive stage is characterized by dominance of reworked quartz and mortar texture formed during the event of dynamothermal metamorphism, (Fig.7c). Plagioclase ranges from albite to andesine $\left(\mathrm{An}_{28}{ }^{-}{ }_{35}\right)$, appears as hypidiomorphic and xenomorphic crystals show cloudy appearance characterized by medium grain size with lamellar and Carlsbad twinning. In this zone, plagioclase shows directional orientation, (Fig. 7d) and moderately affected by stress represented by breaking, bending and then dislocation of plagioclase, (Fig. 7e).

Potash feldspars are the least dominant feldspar represented mainly by orthoclase, perthites, microcline and microcline perthite. Perthites occur as euhedral to subhedral crystals of string type, (Fig. 7f) and patchy perthite enclosing finer crystals of apatite. Microcline is present as strained crystals exhibiting its characteristic cross-hatched twinning, (Fig. 7g). Muscovite occurs as secondary irregular flakes associating the reworked quartz (see fig.7c), while biotite is present as stretched and foliated flakes producing the gneissose texture (Fig. 7h). Rare crystals of Lepidolite (Li-mica) were recorded as platy crystals with violet color and gray interference color, (Fig.8a). 
Petrology and Uranium Potentiality of Abu-Rusheid Subsurface

Accessory minerals are mostly represented by zircon, xenotime, apatite and secondary uranophane. Zircon is present as long prismatic crystals of tetragonal system, (Fig. 8b) and as short prismatic crystals. Some crystals are tectonized and present as anhedral crystals and others are enriched by radioelements; partially
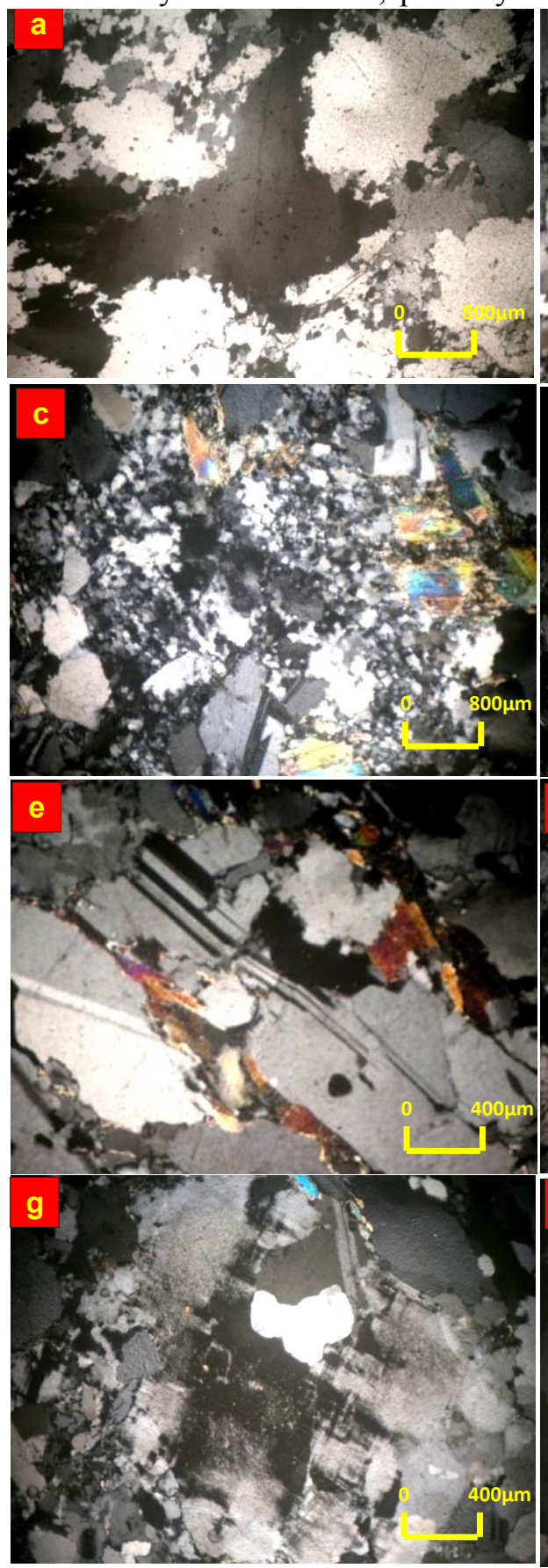

metamectized and surrounded by pleochroic halos in biotite. Xenotime occurs as yellowish brown to bluish color, taking stubby bipyramidal crystals with short prisms and noticeable elongate fractures resulted from the intersected perfect [010] cleavage, (Fig. 8c). Apatite is found as rare minute prismatic crystals included in per-
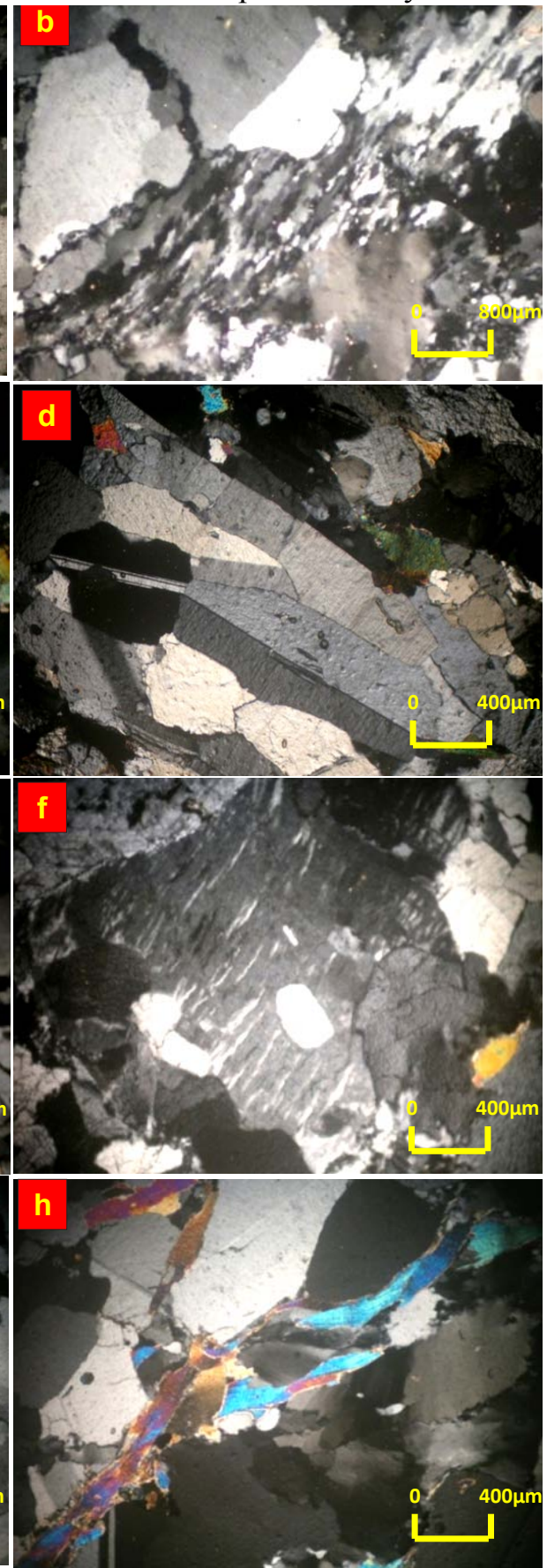

Fig. 7: Photomicrographs in whitish gray granoblastic gneiss of BH1 showing:- a- Quartz crystals with sutured boundries (C.N.). b- Streched crystals of quartz forming fussy texture (C.N.). c- Fragmented quartz forming mortar texture (C.N.). d- Oriented crystals of plagioclase with Carlsbad twinning (C.N.). e- Deformed crystal of plagioclase with dislocation (C.N.). f- Anhedral crystal of string perthite (C.N.). g- Strained crystal of microcline with cross hatching (C.N.). h- Foliated flakes of biotite (C.N.). 
thite and quartz. Some visible secondary uranium mineralization was recorded at depth $23-24 \mathrm{~m}$ as amorphous yellow material associated with hematite filling the late-stage fractures, (Fig. 8d).

The metasomatic minerals that recorded in the studied gneiss are cordierite, garnet and anthophyllite. Cordierite is present as subhedral crystals characterized by discontinuous polysynthetic twinning with wedged lamellae, (Fig. 9a).

Anthophyllite occurs as hypidiomorphic porphyroblast, partially and completely transformed to aggregates of iron oxide, carbonate and chlorite, (Figs. 9b).

According to Helgeson and others (1978);

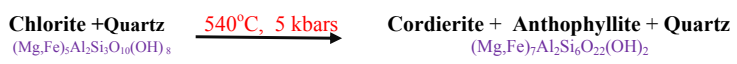

Garnet commonly, occurs as euhedral rounded crystals, (Fig. 9c) and as tectonized crystals; both of them associated with mantle of muscovite suggesting that it is a secondary metamorphic mineral formed by metasomatic process for the mica minerals, (Fig. 9d).

Pinkish dark-gray porphyroblastic gneiss is massive, medium-grained rock characterized by pinkish dark-gray color with porphyroblastic texture, (Fig. 5e).

Under the microscope, it has granodioritic composition; composed mainly of quartz (43\%), plagioclase $(31 \%)$, potash feldspare $(10.2 \%)$ and biotite (14.3\%). Quartz occurs as subhedral crystals with average size about $0.2 \mathrm{~mm}-2.5 \mathrm{~mm}$; it is also present as elongated porphyroblast. Plagioclases appear as euhedral crystals exhibiting lamellar twining, sometimes partially altered to saussurite due to moderate alteration. Potash feldspars are mainly represented by porphyroblasts of perthite, occurring as stretched and oriented aggregates of string perthite, patch perthite and flame perthite, (Fig. 10a). Mica minerals are present mainly as foliated flakes of biotite, (Fig. 10b) with appreciable amount of muscovite. Accessory minerals comprise apatite, zircon, fluorite and opaques. Zircon occurs either as minute crystals included in biotite surrounded by strong pleochroic halos due to radiogenic effect, (see fig. 9b) or as euhedral crystals zoned and twinned crystals, (Fig. 10c). Fluorite occupies the interstitial spaces between the essential minerals, (Fig. 10d) or as tiny crystals included in quartz.

\section{B) Gneissic rocks of borehole (2) BH2}

Gneisses of the second borehole resembles those of the first borehole in composition but characterized by signs of sever tectonism represented by intensive foliation, ribbon texture, kinking, fracturing, and carbonate veinlets. Metasomatic minerals are also different represented by kyanite and cordierite where the anthophyllite and garnet minerals are completely disappeared.

Whitish gray granoblastic gneiss consists of quartz, K-feldspars, plagioclase, together with biotite, muscovite. Plagioclase occurs as oriented euhedral crystals exhibiting albitic twinning with deformed lamella in association with bending and dislocation, (Fig. 3.11a). Potash feldspars are present as subhedral crystals with corroded boundaries mainly as string perthite and microcline, (Fig.11b). Quartz is intensively tectonized and elongated forming ribbons; it is characterized by undulose extinction and microfolding, (Fig.11c). Mica minerals are mainly biotite and rarely muscovite; they are foliated and kinked. The rock is highly fractured and dissected by a number of carbonate veinlets, (Fig.11d). Accessory minerals are mostly represented by euhedral and highly fractured crystals of zircon, (Fig.11e). Rare crystals of monazite were also recorded, (Fig.11f). Metasomatic minerals are mainly cordierite and kyanite. Cordierite is characterized by discontinuous polysynthetic twinning, (Fig.11g). Kyanite is a common mineral in pelites associated with high-medium pressure metamorphism. It is characterized by high relief, two sets of cleavage with angle $85^{\circ}$, moderate order interference colors and simple twinning, (Fig. 11h).

Pinkish granoblastic gneiss is mediumgrained with pinkish color. It has a granoblastic texture, (Fig.12a) and granodioritic composition. It is composed mainly of K-feldspars (26.11\%), plagioclase $(21.39 \%)$, quartz (38\%) and biotite (11.4\%). Plagioclase commonly shows Carlsbad twinning corroded by quartz, (Fig. 12b). K-feldspars are generally represented by microcline and perthite. Microcline occurs as subhedral crystal corroded by quartz and plagioclase, (Fig. 12c). Perthite occurs as string-perthite porphyroblastic crystals, (Fig. 12d). Quartz occurs as subhedral to unhedral crystals exhibit undulatory extinction and have serrate boundaries. Sometimes, quartz crystals enclose radioactive minerals and surrounded by damaged zone (glassy zone), (Fig. 12e). Biotite is foliated alternating with the quartzo-feldspathic components producing the gneissose texture. Inclusions of radioactive minerals are abundant in the biotite flakes, which commonly exhibit pleochroic halos, (Fig. 12f).

Zircon, allanite, thorite and opaques (2.5\%) are the main accessory minerals. Zircon is characterized by its very high relief, colorless and rimmed by iron oxides, it is occasionally zoned. Sometimes, they are fractured, metamicted and surrounded by pleochroic haloes due to radiation damage from 

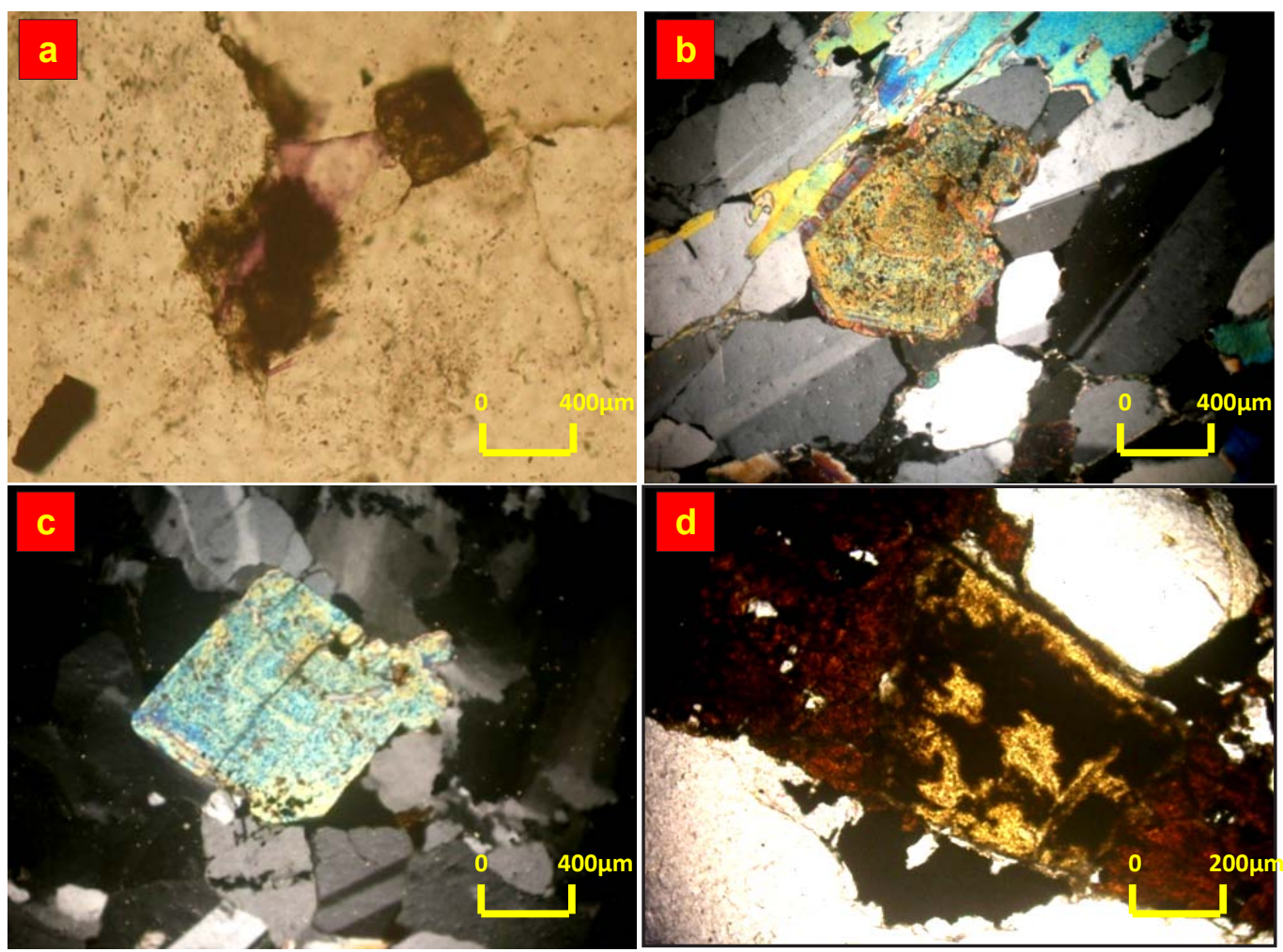

Fig. 8: Photomicrographs in whitish gray granoblastic gneissof BH1 showing:-a- Violet flake of lepidolite and metamectizedzircon (P.P.L). b- Well-formed crystal of zircon(C.N.).c- Well-formed crystal of xenotime (C.N.).d- Fracture filled by amorphous radioactive mineraland iron oxides(C.N.).
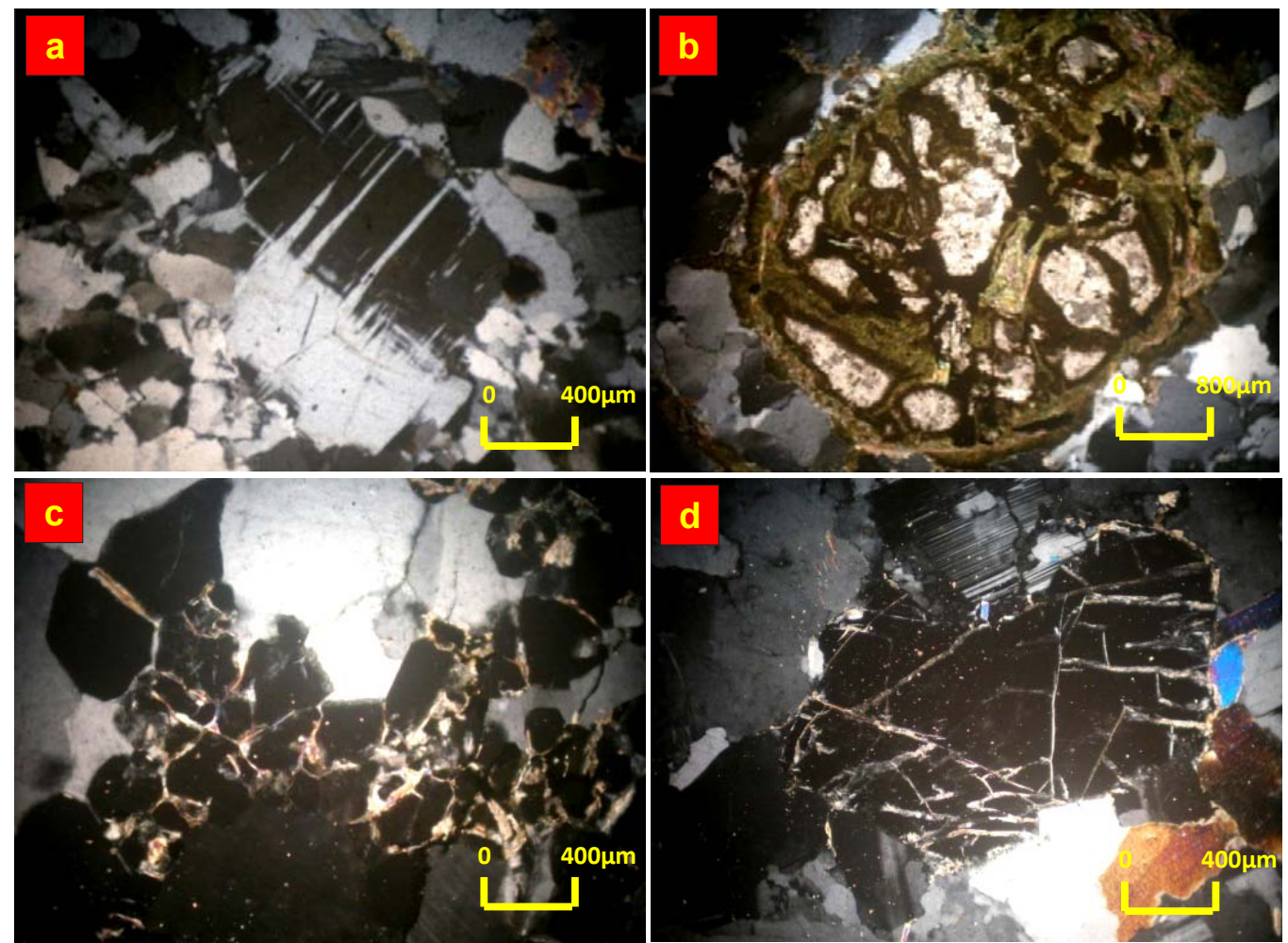

Fig. 9: Photomicrographs in whitish gray granoblastic gneissof BH1showing:-a- Cordierite with polysynthetic twining (C.N.).b- Anthophylliteporphyroblast partially replaced by iron oxide + carbonate + chlorite (C.N.). c- Polygonal crystals of garnet(C.N.). d- Fractured (tectonized) garnet with relics of muscovite(C.N.). 

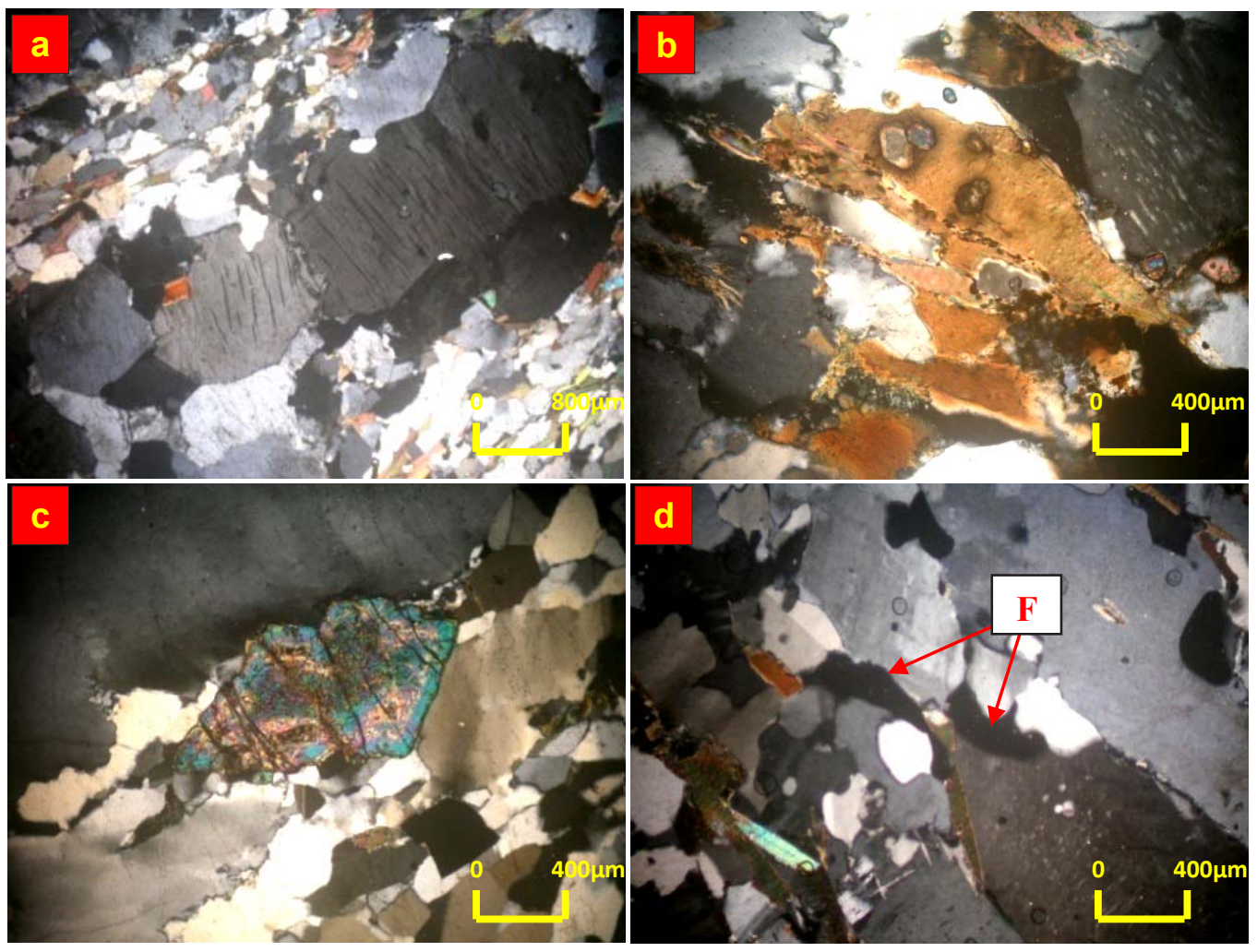

Fig. 10: Photomicrographs in pinkish dark-gray porphyroblastic gneissof BH1 showing:-a- Oriented aggregates of string perthite as a porphyroclast (C.N.). b- Zircon in biotite surrounded by pleochroic haloes (C.N.). c- Twinned crystals of zoned zircon (C.N.).d- Interstitial fluorite (F) associating quartz and feldspar (C.N.).

the radioactive inclusions. Allanite occurs as subhedral to unhedral crystals varying from reddishbrown crystals to dark honey yellow color.

\section{RADIOACTIVE MINERALS}

The radioactive minerals are separated from the bulk radioactive samples by heavy liquid separation. The heavy fractions were then magnetically fractionated at different current intensities. Mineral grains were picked from each of the obtained heavy fractions under binuclear microscope. Some of these selectively picked grains were subjected to X-ray diffraction technique (XRD), others of the separated grains were examined by Environmental Scanning Electron Microscope (ESEM) Phillips EXL 130 and attached by EDX unite system. Also, some thin sections were also prepared and analyzed by the ESEM, so $\mathrm{Si}, \mathrm{Al}, \mathrm{Fe}$ and $\mathrm{Ca}$ will be increase in the analysises. All these analysises were carried out on the Laboratories of the Nuclear Materials Authority (NMA), Cairo, Egypt and ElTebbein Institute for mineralogical studies, Cairo, Egypt.

The obtained radioactive minerals can be classified into:

1- Uranium minerals including uranophane

2- Thorium minerals including thorite and uranothorite
3- Radioelements-bearing minerals comprising columbite, pyrochlore, betafite, samarskite, fergusonite and zircon

Uranophane $\left(\mathrm{CaO} .2 \mathrm{UO}_{3} .2 \mathrm{SiO}_{4} \cdot 6 \mathrm{H}_{2} \mathrm{O}\right)$ crystals were found in the heavy fractions of samples No. $23 \mathrm{~m}$ and $24 \mathrm{~m}$ (23m-24m depths) of BH1 only. Under the binocular microscope, uranophane is characterized by their softness, ability to crush by needle. It is generally massive with granular form and characterized by dull and/or greasy luster. Pure monomineralic mineral grains of uranophane were picked under the binocular microscope, (Fig. 13a) and show that the uranophane grains occur as radiated massive aggregates with granular forms as well as dense microcrystalline masses. The SEM analyses of uranophane grains are shown in (Fig. 13a). It contains $\mathrm{U}=25.98 \%$ atomic percent, $\mathrm{Ca}$ $=10.63 \%$ atomic percent, and associated element represented by $\mathrm{K}=7.90 \%$ atomic percent.

Thorite $\left(\mathrm{ThSiO}_{4}\right)$ is a strongly radioactive mineral, brown to black, tetragonal crystal. Thorite mineral may contain as much as $10 \%$ uranium. Thorite occurs as metamictized, short prismatic crystals exhibiting deep brownish color. It is confirmed by SEM, (Fig.13b).

Uranothorite (U, $\mathrm{Th}) \mathrm{SiO}_{4}$ occurs as anhedral to subhedral metamicted crystals. Grains of ura- 

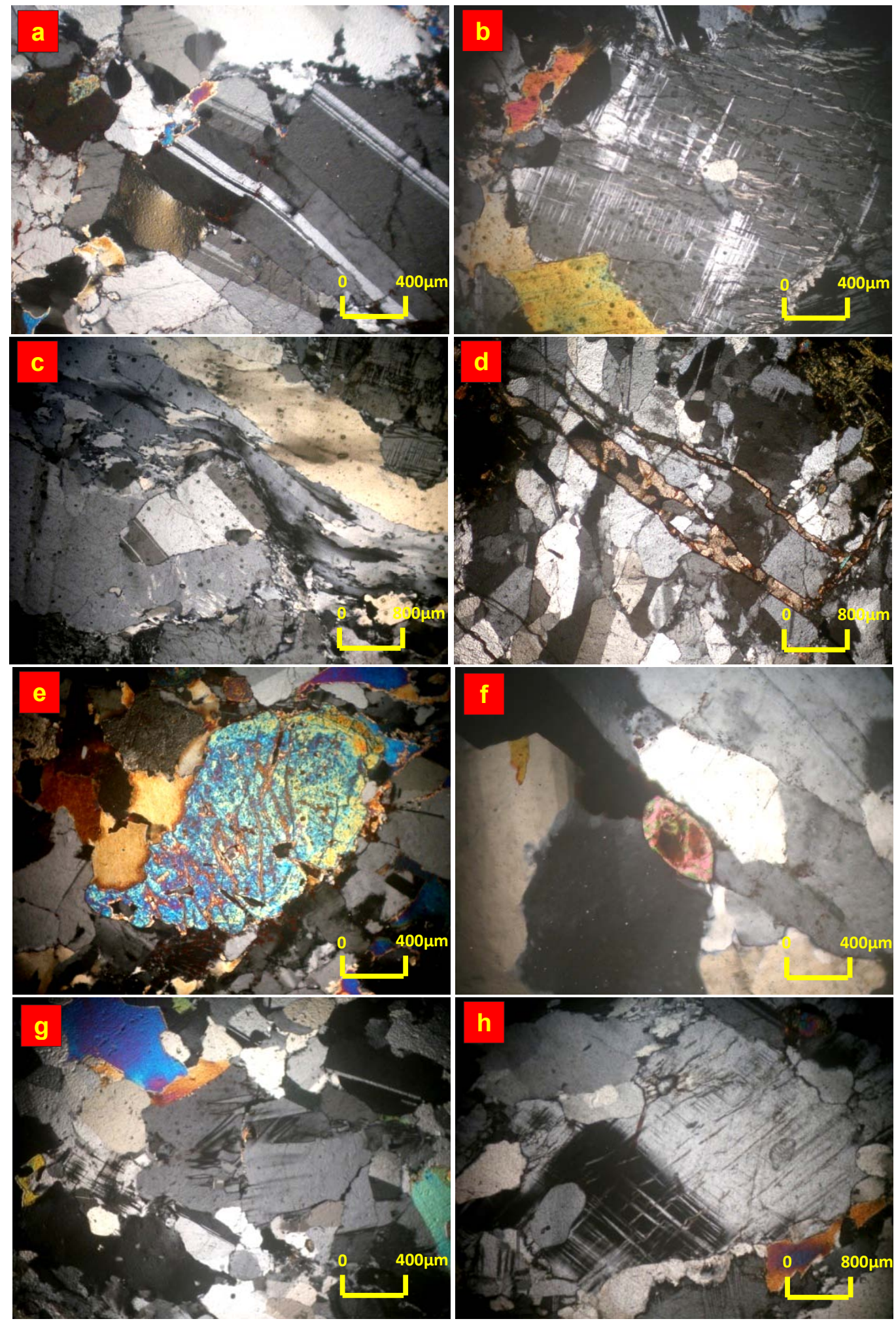

Fig. 11: Photomicrographs in whitish gray granoblastic gneissof $\mathrm{BH} 2$ showing:a- Dislocation in plagioclase (C.N.). b- Microcline with corroded boundaries (C.N.). c- Elongated quartz forming ribbon texture (C.N.). d- Fractures filled by carbonate. e-Tectonized and fractured crystal of zircon (C.N.). f- Well-formed crystal of monazite (C.N.). g- Cordierite with polysynthetic twining (C.N.). h- Subhedral crystal of kyanite(C.N.). 

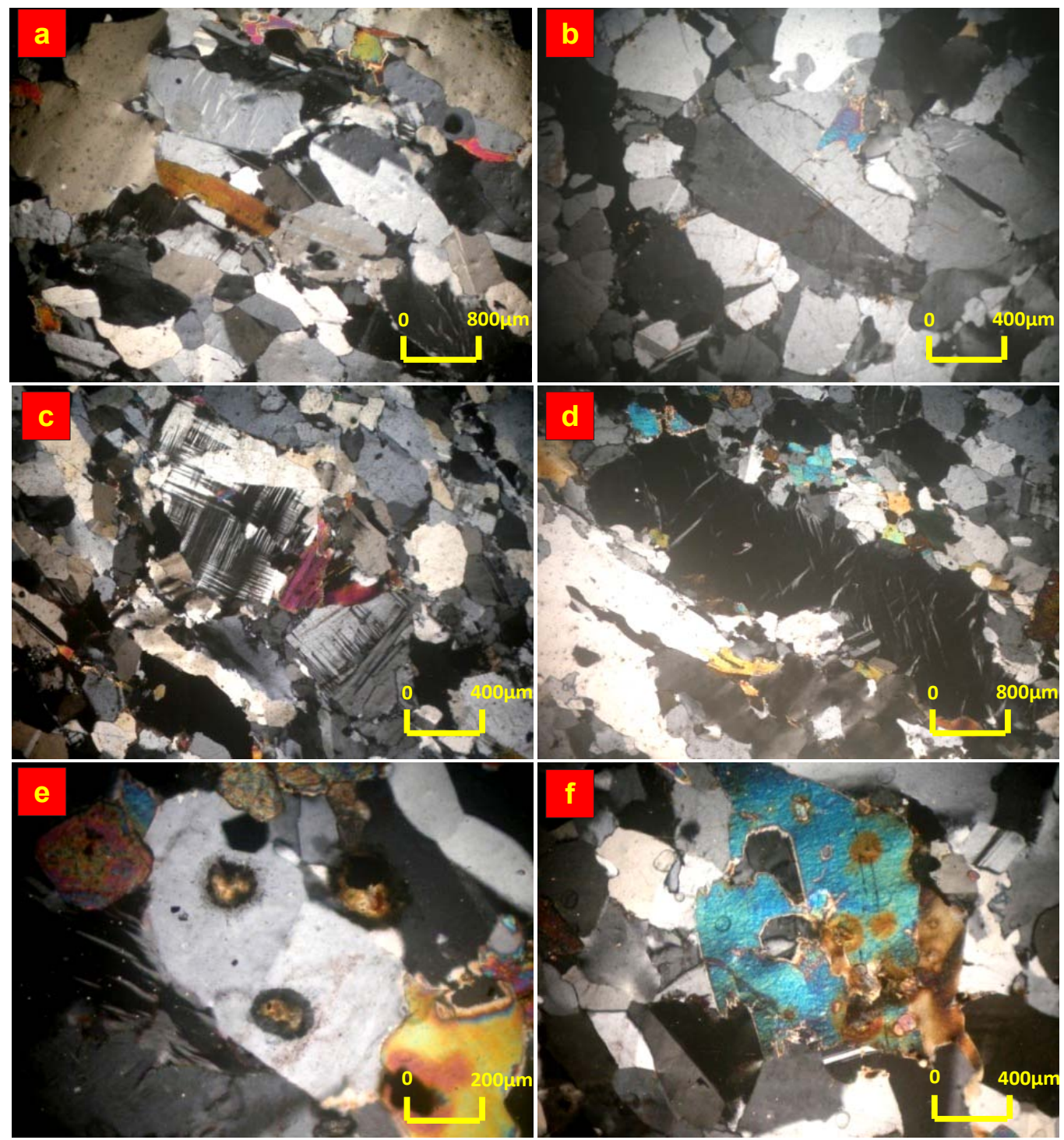

Fig. 12: Photomicrographs in pinkish granoblastic gneiss ofBH2showing: -a- Quartz, biotite and perthite showing granoblastic texture (C.N.).b- Deformed plagioclase showing Carlsbad twinning (C.N.). c- Microcline crystal (C.N.). d- Porphyroblast of perthite (C.N.).e- Radioactive spots in quartz surrounded by damaged zone (glassy zone) (C.N.).f- Radioactive crystals included in biotite andsurrounded by pleochroic halos (C.N.).

nothorite are brownish orange and orange in large masses and has dull luster, (Fig. 13c). Cleavage is not apparent in metamict crystal. The semi-quantitative ESEM analysis of some uranothorite grains shows that $\mathrm{Th}, \mathrm{U}$ and $\mathrm{Si}$ contents in average are $52.84 \mathrm{wt} \%, 16.51 \mathrm{wt} \%$ and $25.2 \mathrm{wt} \%$, respectively, (Fig. 13c). Thorite and uranothorite minerals represent the main radioactive minerals identified in the studied rocks where they were found abundantly in whitish gray granoblastic gneisses of $\mathrm{BH} 1$ and $\mathrm{BH} 2$ and pinkish granoblastic gneiss of $\mathrm{BH} 2$ as dissiminated crystals.

There are five varieties of niobium minerals detected in psammitic and granitic gneisses in addition to zircon.

1- Ferrocolumbite $\left.\left[(\mathrm{Fe}, \mathrm{Mn})(\mathrm{Nb}, \mathrm{Ta})_{2} \mathrm{O}_{6}\right)\right]$ is generally black to deep brownish color at their thin edges and possesses a brilliant metallic luster, occurs as flattened, irregular angular grains with sharp edges and some grains showing black thin tabular crystals and also as massive compact and heart shaped grains, (Fig. 14a). The ESEM data shows that the columbite is distinctly enriched in $\mathrm{Nb}$ with presence of U $16.52 \mathrm{wt} \%$, Th $5.02 \mathrm{wt} \%$ and $\mathrm{Ta} 7.41 \mathrm{wt} \%$. The columbite mineral is highly ferruginated, with $\mathrm{Fe} 3+$ content reaching from 3.4 $\mathrm{wt} \%$ to $22.00 \mathrm{wt} \%$, while $\mathrm{Mn}$ is reported as 6.88 wt $\%$, (Fig. 14a).

2- Pyrochlore [(Fe, Mn) ( $\left.\mathrm{Nb}, \mathrm{Ta}, \mathrm{Ti}) \mathrm{O}_{4}\right]$ is recorded in the mineralized whitish gray granoblastic gneiss. It is occurs as subhedral crystals and confirmed by SEM, (Fig. 14b). The major elements for pyrochlore include $\mathrm{Nb}, \mathrm{Ti}, \mathrm{Ta}, \mathrm{Fe}$, and $\mathrm{Mn}$. It is considered as low-Ti pyrochlore with Ti content reaching $1.70 \mathrm{wt} \%$. 
3- Betafite [(Fe, Ca, Th, U) (Ti, Nb, Ta) $\mathrm{O}_{6} \cdot \mathrm{nH2O}$ ] was found as an alteration phase, very dark in color, containing potential concentrations of the high-field-strength elements (HFSE), such as $\mathrm{Ti}, \mathrm{Nb}$, and $\mathrm{Ta}$, besides $\mathrm{U}$; these were obtained by SEM-BSE images, (Fig. 14c).

4- Yttrocolumbite or Samarskite the probable formula of yttrocolumbite is $\mathrm{AB}_{2} \mathrm{O}_{5}$ (Heinrich, 1958): $\mathrm{A}=\mathrm{Y}$ and Ce group with $\mathrm{U}, \mathrm{Th}, \mathrm{Fe}^{2+}, \mathrm{Ca}$ and $\mathrm{B}=\mathrm{Nb}, \mathrm{Ta}, \mathrm{Nd}, \mathrm{Gd}$ and $\mathrm{Fe}^{3+}$. Frondel and Fleissher (1955), and Rosenqvist (1949) believe that samarskite forms the $\mathrm{Nb}$-rich end member of a series, and yttrotantalite forms the Ta-rich end member. Thus the name yttrocolumbite (Lepierre, 1937) is probably a synonym for samarskite. Yttrocolumbite or samarskite is a complex oxides, mainly of $\mathrm{Nb}$ and $\mathrm{Ta}$ and Y-group rare-earth elements with significant amounts of $\mathrm{U}$ or both $\mathrm{Th}$ and $\mathrm{Ca}, \mathrm{Fe}^{2+}$. The obtained EDX analysis shows that; $\mathrm{Nb}$ reaches up to $66.02 \mathrm{wt} \%$, and $\mathrm{Y} 19.35 \mathrm{wt} \%$, (Fig. 14d). The $\mathrm{U}$ and $\mathrm{Fe}^{2+}$ have been reported with amount of 7.17 $\mathrm{wt} \%$ and $6.05 \mathrm{wt} \%$, respectively.

5- Fergusonite (Nb, Y, Ta, U, Al, Mg, Fe, REE) the fergusonite is a mineral comprising a complex oxide of various rare earth elements. It presents in the form of tabular prismatic shape which containing potential concentration of the high field strength elements (HFSE) such as $\mathrm{Nb}$, $\mathrm{Y}$, Th and Ti, besides U. The obtained EDX analysis exhibits that; $(\mathrm{U}=1.25 \%$ atomic percent, $\mathrm{Nb}=$ $35.42 \%$ atomic percent, $\mathrm{Ta}=1.62 \%$ atomic percent and $\mathrm{Y}=20.98 \%$ atomic percent this was confirmed by ESEM, (Fig. 14e). The crystallization of the fergusonite is closely related to hydrolysis of $\mathrm{REE}$ and $\mathrm{Nb}$ complexes.

The previous microanalysis shows that the niobium-hosting minerals are the main contributer in the radioactive potentiality of the Abu-Rusheid gneisses.

Thorium rich zircon. Zircon can form under nearly all geological conditions, including magmatic, hydrothermal, metasomatic and metamorphic (e.g. Rubin et al., 1989; Claoue-Long et al., 1990; Black et al., 1991; Vavra et al., 1996; Rubatto et al., 1999). The metamict state (breakdown of the structure) in zircon may be due, at least in part, to the presence of radioactive atoms (Deer et al., 1966). Metamictization process causes radial and concentric fractures, which are good pathways for uranium leaching or addition (Deer et al., 1966). Based on crystal morphology, Zircon from Abu Rushied gneissic rocks can be subdivided into three types; igneous type, mud type, and tectonized type.

The first type is tetragonal crystals with mea- surable prismatic faces (long-prismatic), (Fig. 15a); while the second type is tetragonal crystals with diminished prismatic faces (short-prismatic), (Fig. 15b).

The third type occurs as anhedral and fractured crystals, (Fig. 15c) affected by tectonism; this type is more common in the dynamically metamorphosed rocks and it is widely present in $\mathrm{Abu}$ Rusheid gneisses. Figs.16.a, 16b and 16c show the analyses of the different types of studied zircon using the (ESEM) indicate evident of chemical and crystallographic distortion; it is composed essentially of $\mathrm{ZrO}_{2}$ and $\mathrm{SiO}_{2}$. The analyses also show the substitution of $\mathrm{Zr}$ by Hf, Th, and U. Fe which occur as inclusions and staining Fe-oxi-hydroxide.

\section{DISCUSSION AND CONCLUSIONS}

The underlying units in BH1 are lithologically represented mainly (from top to bottom) by quartzhornblende schist, serpentinite, whitish gray granoblastic gneiss alternating after $46 \mathrm{~m}$ depth with pinkish gray porphyroblastic gneiss with sharp contacts. While, the core samples of the $\mathbf{B H} \mathbf{2}$ are mainly comprised (from top to bottom) of whitish gray granoblastic gneiss, pink granoblastic gneiss, quartz-feldspar-biotite schist, quartz-hornblendebiotite schist, mica schist, talc carbonate (represent another deformed melange body), gray granoblastic gneiss with migmatite zone and finally whitish gray granoblastic gneiss.

Gneisses of the second borehole resemble those of the first borehole in composition but characterized by signs of sever tectonism represented by intensive foliation, ribbon texture, kinking, fracturing, and carbonate veinlets. Metasomatic minerals are also different and represented by kyanite and cordierite where the anthophyllite and garnet minerals are completely disappeared.

In the present study, whitish gray granoblastic gneiss is classified as psammitic gneiss due to: 1) Its relatively lower relief compared to granitic rocks, 2) Their high silica contents (more than $80 \% \mathrm{SiO} 2$, in average, Abd El-Naby and Frisch, 2006), 3) Their high contents of quartz grains, mostly of equal sizes, 4) The presence of cordierite and kyanite which are considered as a pelitic minerals, 5) Quartzo-feldspathic composition with abundance of relict detrital zircon and other heavy minerals, 6) Separated zircon grains from the rocks gave $\mathrm{U} / \mathrm{Pb}$ age of $1770 \mathrm{Ma}$ that interpreted as a probable age of the crustal area that supplied the detritus forming the original sediments (Abdel Monem and Hurley, 1979).

The pinkish dark-gray porphyroblastic gneiss of $\mathrm{BH} 1$ and pinkish granoblastic gneiss of $\mathrm{BH} 2$ is petrographically identical to granodioritic rocks 
(clearly granitoid composition, lake of pebbles and pelitic minerals such as cordierite and kyanite) alternated with whitish gray granoblastic gneiss of sedimentary origin and the metamorphic sequence most likely represents a sequence of pelites and psammites, intruded by megacrystic granitoid injections from external sources then metamorphosed to an amphibolites-granulite facies assemblage. The presence of the metasomatic minerals (cordierite, kyanite, garnet and anthophylite is indicative of a low-pressure facies series at hornblende-granulite grade (DeWaard, 1966; Green \& Ringwood, 1967; Abscher \& McSween, 1985).

Based on the lithostratigraphic description and geochemical characteristics of the igneous suites in the two pre-pilot drill holes and their evolution through time from ultrabasic to acidic suggests a tectonic evolution similar to that of modern island arcs of El Ramly et al., 1984 and Kroner et al., 1987 with some modifications, which can be summarized as follows:
The pre Pan-African rocks are represented by paragneisses, these para-gneisses in association with biotite gneisses represent the oldest rock units. Their sedimentary origin is in line with the conclusions of Dixon (1981) who found pebbles and cobbles in clastic metasediments in the Dahanib area to the south of Marsa Alam with ages between 1120 and $2060 \mathrm{Ma}$, this is agrees with the presence of pebbles in paragneiss of the study area. During Pan-African times clastic sediments of continental and / or mature island arc derivation were deposited along an active continental margin in a basin floored by an oceanic crust.Somewhat later, northwestward subduction resulted in the generation of calc-alkaline magma and the formation of the Hafafit island arc (s).Continued subduction and maturation of the Hafafit island arc caused early deformational phases D1-D4 and the metamorphic episodes M1 and M2. Early collision, probably arc-arc, between the Hafafit island arc and another arc to its northwest lead to a phase of shearing and thrusting (D 5). Subsequently D6 and D7 were

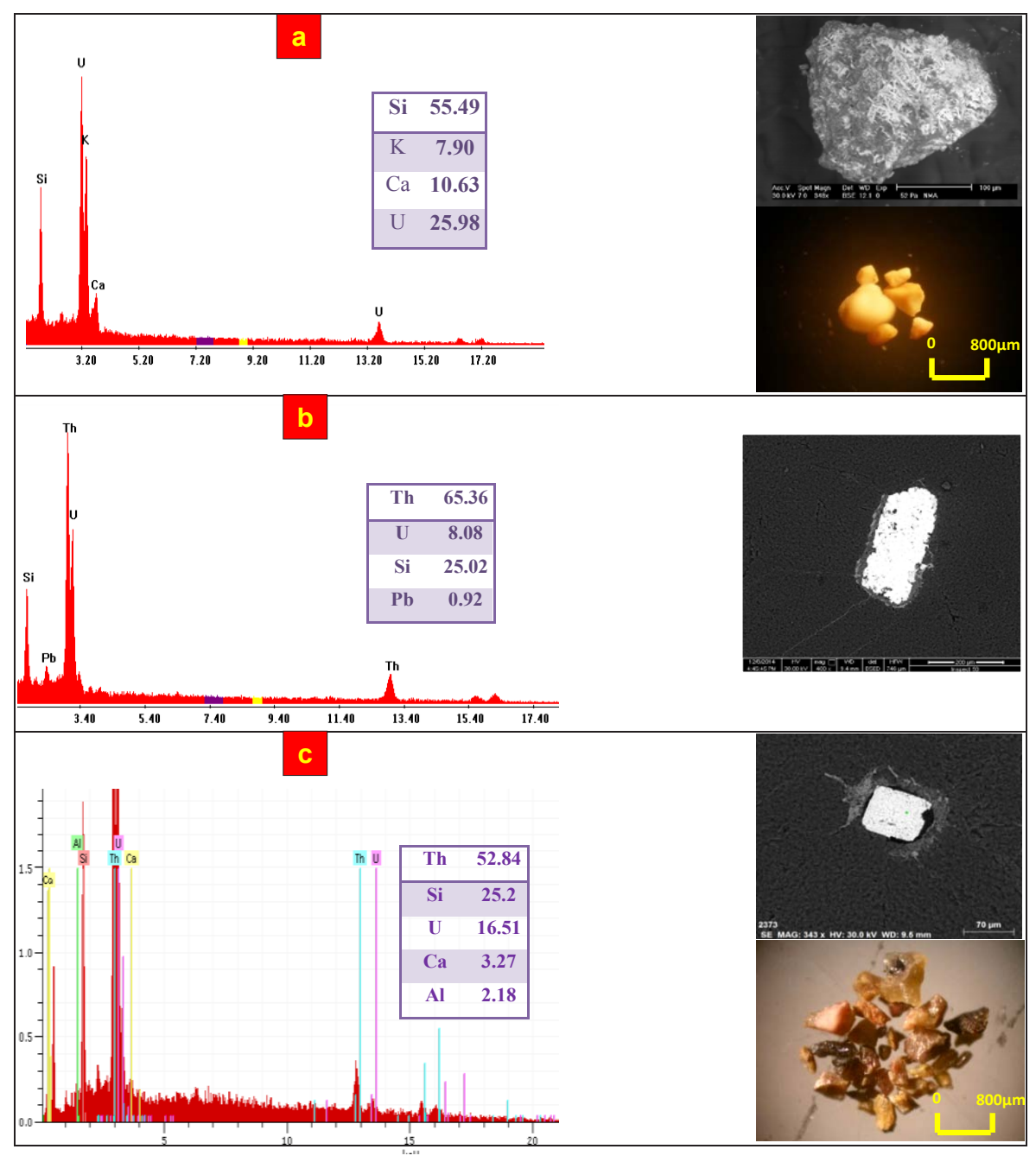

Fig. 13: Photographs, EDX and BSE image showing: a-Uranophane grain andseparated uranophane grains.b-Thorite grain. c-Uranothorite grain and separated Uranothorite grains 
Petrology and Uranium Potentiality of Abu-Rusheid Subsurface

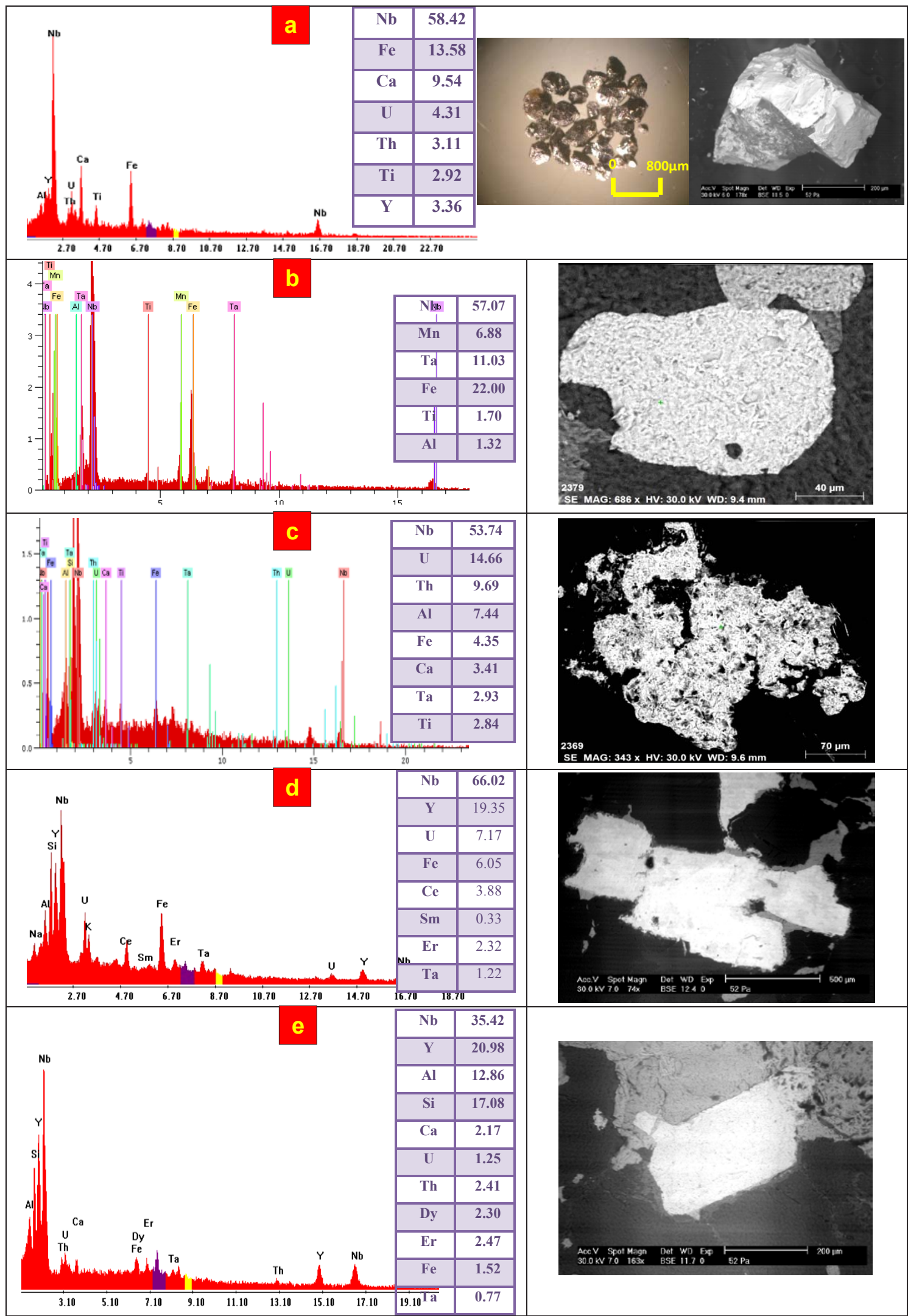

Fig. 14: EDX and BSE image showing:a-Ferrocolumbitegrain. b- Pyrochloregrain.c-Betafite grain. d- Samarskitegrain.e-Fergusonite grain. 

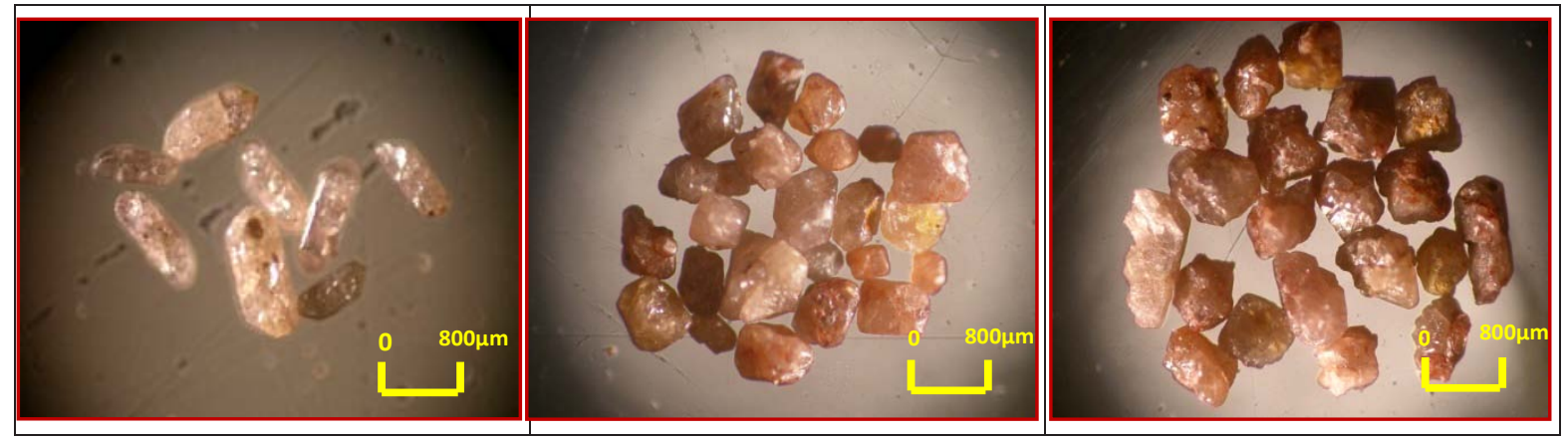

Fig. 15: Photomicrograph of studied zircon showing;-a- Elongated zircon grains of igneous type.b-Zircon grains of mud type. c- Tectonized type (anhedral zircon)

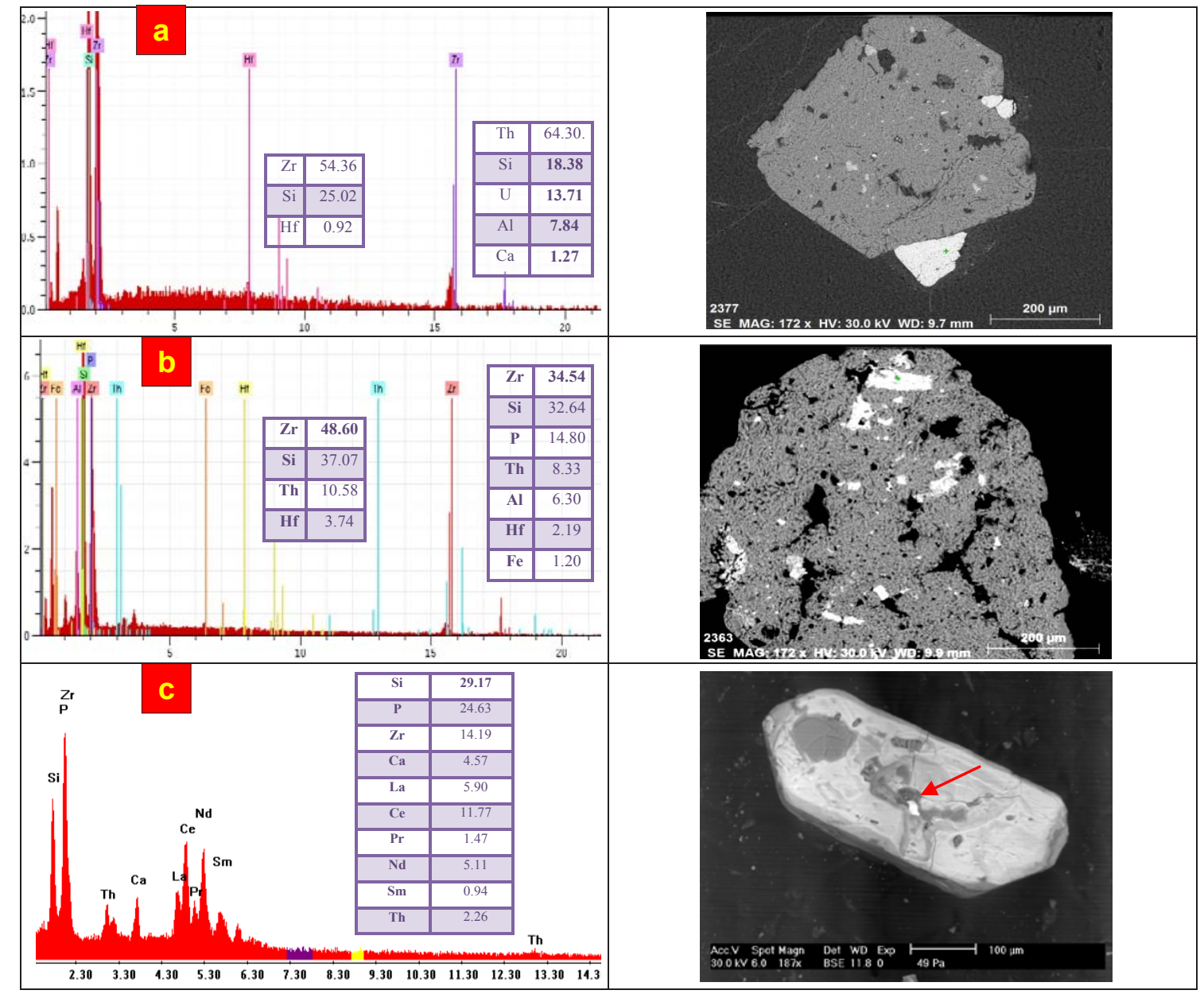

Fig. 16: EDX and BSE image showing:a-Zircon of mud type.b- Recrystallized zircon type.c-

Zircon of igneous type with monazite inclusion. generated as fault-bend folds. El Bayoumi and Greiling (1984) suggested that this collision initiated compression and granitoid magmatism in Wadi Nugrus (younger granites). Late collision (arc-arc) may be explained by the approach of another volcanic arc, advancing from further southeast. During this stage the Nugrus melange and Wadi Ghadir ophiolite were obducted onto the eastern part of Wadi Hafafit by the regional thrusting D8. Regional nappe transport was in a SE-NW direction. Minor gravitational doming coupled with a vertical

stress field probably due to a gravity inversion accentuated the conspicuous granitoid-cored domes and modified the D10 and older folds. The magmatic development ended with the emplacement of large granitoide complexes often of batholitic proportions and related to the older granite event of the Eastern Desert (El Ramly and Saleeb Roufaiel 1974). To sum up, the low grade rock assemblage represents the upper part of an island arc together with fragments of sediments and oceanic crust derived from a fore arc/trench tectonic environment. 


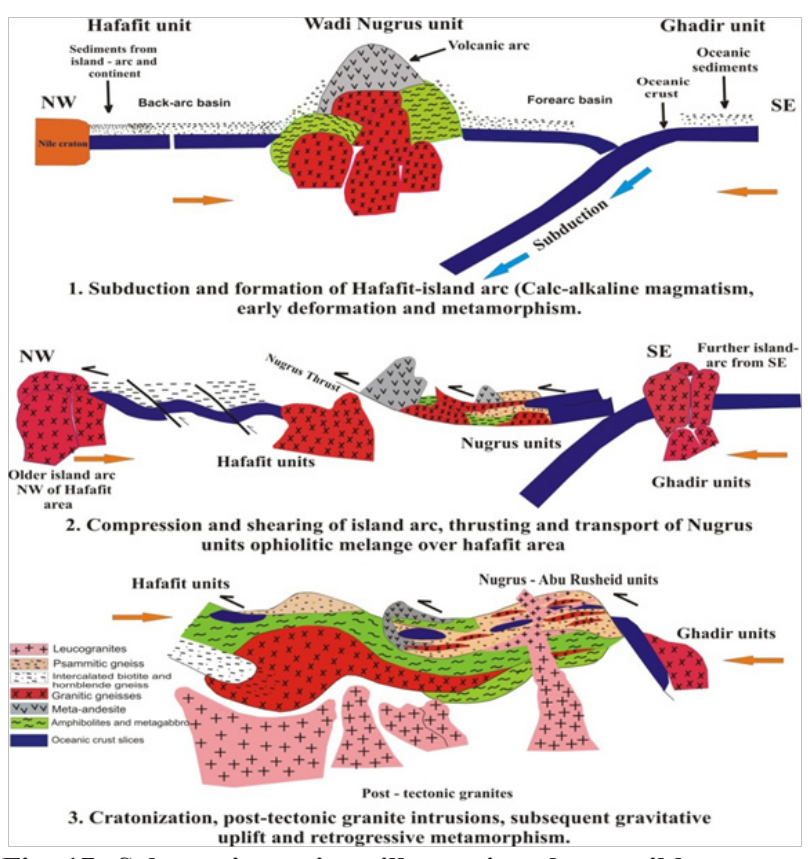

Fig. 17: Schematic sections illustrating the possible geotectonic evolution of the Migif-Hafafit, Nugrus, Abu Rusheid and Ghadir areas (modified after El Ramly et al., 1993)

Subsequent thrusting led to the disruption of the island arc and placed the different structural levels side by side. Thrusting was succeeded by further acidic intrusive activity (Fig. 17).

The detailed mineralogical studies proved presence of radioactive minerals comprising primary uranium mineral such as uranothorite, secondary uranium minerals such as uranophane as well as rare metal mineral species such thorite, niobium minerals (columbite, pyrochlore, betafite, samarskite and fergusonite), xenotime, zircon and monazite along the two drillholes. Finally, although these minerals are highly stable, the strong oxidized fluids partially alter them and some of their uranium has been released and redeposited along the shear zones. Hence, it is worthy to mention here that, thorite, uranothorite, uranophane, niobium-hosting minerals, zircon, xenotime and monazite are the main contributor in the radioactive potentiality of the Abu-Rusheid gneisses.

\section{REFERENCES}

Abd El-Naby, H., Frisch, W., (2006): Geochemical constraints from the Hafafit Metamorphic Complex (HMC): evidence of Neoproterozoic back-arc basin development in the central Eastern Desert of Egypt. Journal of African Earth Science, 45, 173-186.

Abd El-Naby, H.H. and Frisch, W., (2002): Origin of the Wadi Haimur-Abu Swayel Gneiss belt, South Eastern Desert, Egypt: Petrological and geochronological constraints, Precambrian Research, 113: 307322.

Abd El-Naby, H., Frisch, W., Hegner, E., (2000): Evolution of Pan-African Wadi Haimur metamorphic sole, East- ern Desert, Egypt. Jounal of Metamorphic Geology, 18, 639-651.

Abdel-Monem, A.A. and Hurley, P.M., (1979): U-Pbstaing of zircons from psammitic gneisses, Wadi Abu Rusheid-WadiSikait area, Egypt, Institute of Applied Geology, Jeddah, 3 (2): 165-170.

Absher, S. B., \&McSween, H. Y., (1985): Granulites at Winding Stair Gap, North Carolina; the thermal axis of Palaeozoic metamorphism in the southern Appalachians. Bull. Geol. Soc. Am. 96, 588-99.

Black, L. P., Kinny, P. D. and Sheraton, J. W., (1991): The difficulties of dating mafic dikes: an Antarctic example. Contributions to Mineralogy and Petrology 109, 183194.

Claoue-Long, J. C., King, R. W. and Kerrich, R., (1990): Archaean hydrothermal zircon in the Abitibi greenstone belt: constraints on the timing of gold mineralization. Earth and Planetary Science Letters 98, 109-128.

Deer, W. A., Howie, R. A. and Zussman, J., (1966): An introduction to rock forming minerals. Longmans, London. p517.

deWaard, D., 1966: The biotitc-cordierite-almandite subfacies of the hornblende granulite fades. Mem. Geol. Soc. Am. 73, 259.

Dixon, T. H., (1981): Age and chemical characteristics of some pre Pan-African rocks in the Egyptian Shield. Precambrian Res. 14, 119-133.

El-Bayoumi, R. M. A. and Greiling, R., (1984): Tectonic evolution of a Pan-African plate margin in southeastern Egypt - a suture zone over printed by low angle thrusting? In: Klerkx, J., Michot, J. (Eds.), African Geology, Tervuren, pp. 47-56.

El-Ramly, M. F., Greilling, R. O., Rashwan, A. A. and Rasmy, A. H. (1993): Explanatory note to accompany the geological and structural maps of Wadi Hafafit area, Eastern Desert of Egypt, Geological Survey of Egypt, Paper No. 68.

El-Ramly, M. F., Greiling, R., Kröner, A. and Rashwan, A. A., (1984): On the tectonic evolution of the Wadi Hafafit area and envi-rons, Eastern Desert of Egypt. Journal of King Abdulaziz University, Earth Sciences, 6, 113-126.

El-Ramly, M. F. and Saleeb Roufaiel, G. S., (1974): Sodic silica metasomatism and introduced zircon in the Migif Hafafit gneisses, Eastern Desert. Egypt. J. Geol. 18, 119-126.

Fowler, A. and Osman, A. F., (2009): The Shait-Nugrus shear zone separating central and south Eastern Deserts, Egypt: A post-arc collision low-angle normal ductile shear zone, Journal of African Earth Sciences, 53: 16-32.

Fritz, H., Wallbrecher, E., Khudeir, A. A., Abu El-Ela, F. F., and Dallmeyer, D. R., (1996): Formation of Neoproterozoic metamorphic core complexes during oblique convergence Eastern Desert, Egypt. J. African Earth Sci., 23, 311-329.

Frondel, J.W. and Fleissher., (1955): Glossary of uranium and thorium bearing minerals. U. S. Geol. Survey Bull. 1015-B.

Green, D. H., \& Ringwood, A. $E^{\wedge}$ (1967): An experimental investigation of the gabbro to eclogue transformation and its petrologic application. Geochim. Cosmochim. 
Ada $31,767-833$

Greiling, R.O., Kröner, A. and El Ramly, M. F., (1984): Structural interference patterns and their origin in the Pan-African basement of the southeastern Desert of Egypt. In: Kröner, A., Greiling, R.O. (eds.). Precambrian tectonics illustrated. Schweizerbart, Stuttgart, Germany, 401-412.

Greiling, R. O., Kr" oner, A., El-Ramly, M. F., and Rashwan, A. A., (1988): Structural relations between the southern and central parts of the Eastern Desert of Egypt: details of a fold and thrusts belt. In: El-Gaby, S., Greiling, R. (Eds.). The Pan-African Belt of the NE Africa and Adjacent Areas. Tectonic Evolution and Economic Aspects. Freidr.Vieweg\&Sohn, Braunschweig/Weisbaden, 121-145.

Hassan, M. A., (1973): Geology and geochemistry of radioactive columbite-bearing psammitic gneiss of Wadi Abu Rusheid South Eastern Desert, Egypt, Annals of the Geological Survey of Egypt, III: 207-225.

Heinrich, E. W., (1958): Minerology and geology of radioactive raw materials, New York, McGraw Hill Comp. $654 \mathrm{p}$.

Helgeson, H. C., J. M. Delany, H. W. Nesbitt, and D. K. Bird (1978): Summary and Critique of the thermodynamic properties of rock forming minerals. Am. J. Sci., vol.1278A.

Hilmy, M. E., El Bayoumi, R. M. and Eid, A. S., (1990): Geology, geochemistry, and mineralization of the psammitic gneiss of wadi Abu Rusheid, Eastern Desert, Egypt. Jour. Afr. Earth Sci., V.II, p.197-205.

Hyndman, D. W., (1985): Petrology of igneous and metamorphic rocks. Second Edition, New York, McGraw Hill Comp. 600 p.

Ibrahim, M. E., El-Tokhi, M. M., Saleh, G. M., Hassan, M. A. and Rashed, M.A., (2007): Geochemistry of lamprophyres associated with uranium mineralization, Southeastern Desert, Egypt, Chinese journal of geochemistry, 26 (4), DOI: 10.1007/s11631-007-03564.

Ibrahim, M. E., Saleh, G. M, Amer, T., Mahmoud, F. O, Abu El Hassan, A. A., Ibrahim, I. H., Aly, M. A., Azab, M. S., Rashed, M. A., Khaleal, F. M. and Mahmoud, M. A., (2004): Uranium and associated rare metals potentialities of Abu Rusheid brecciated shear zone II, south Eastern Desert, Egypt. (Internal report).

Ibrahim, M. E.,Saleh, G. M.,Abd El Naby, H. H. Mahmoud, F. O. Abu El Hassan, E. A. Ibrahim, I. H. Aly, M. A., Azab, M. S. Rashed. M. A, Khaleal, F. M. and Mohamed, A. M., (2002): Uranium and associated rare metals potentialities of Abu Rusheid brecciated shear zone, south Eastern Desert, Egypt. (Internal Report) Part I.

Ibrahim M. E., Assaf H. S. and Saleh G. M., (2000): Geochemical alteration and spectrometric analyses in $\mathrm{Abu}$ Rusheid altered uraniferous gneissose granites, South Eastern Desert, Egypt Chem. Erde 60, 173-188.

Kröner, A., Todt, W., Hussein, I.M., Mansour, M., Rashwan, A.A., (1992): Dating of late Proterozoic ophiolites in Egypt and Sudan using the single grain zircon evaporation technique, Precambrian Research, 59, 15-32.

Kröner, A., Greiling, R.O., Reischmann, T., Hussin, I.M., Stern, R.J., Durr, S., Kruger, J., Zimmer, M., (1987): Pan-African crustal evolutionin the Nubian segment of northeast Africa. In: Kro"ner, A. (Ed.), Proterozoic Lithospheric Evolution, Geodynamics Series, vol. 17. American Geophysical Union, pp. 237-257.

Lepierre, C., (1937): Yttrocolumbite de Mocambbique. Mem. Acad. Cienc. Lisboa, Class Ciencias 1: p. 369375.

Raslan, M., (2008): Occurrence of Ishikawaite (UraniumRich Samarskite) in the Mineralized Abu Rushied Gneiss, Southeastern Desert, Egypt, International Geology Review, 50 (12): 1132 - 1140.

Rosenqvist, I.T., (1949): Samarskit-Yttrotantalit ved Bjortjenn I Mykland Herred. Norsk Geol. Tidssker. V. 28, p. 40-43.

Rubin, J. N., Henry, C. D. \& Price, J. G. (1989): Hydrothermal zircons and zircon overgrowths, Sierra Blanca Peaks, Texas. American Mineralogist 74, 865-869.

Stern, R. J., (1985): The Najd fault system, Saudi Arabia and Egypt: a Late Precambrian rift-related transform system $\square$ : Tectonics, Vol. 4, pp. 497 - 511s.

Vavra, G., Gebauer, D., Schmid, R. \& Compston, W., (1996): Multiple zircon growth and recrystallization during polyphase Late Carboniferous to Triassic metamorphism in granulites of the Ivrea Zone (Southern Alps): an ion microprobe (SHRIMP) study. Contributions to Mineralogy and Petrology 122, 337-358. 